\title{
Vitamine B12 deficiency in children : a diagnostic challenge
}

\author{
J. Van Vlaenderen, J. Christiaens, M. Van Winckel, R. De Bruyne, S. Vande Velde, S. Van Biervliet \\ Department of Paediatric Gastroenterology, University Hospital Ghent, Corneel Heymanslaan 10, 9000 Ghent, Belgium.
}

\begin{abstract}
Cobalamin or vitamin B12 (vitB12) is involved in DNA synthesis, haematopoiesis and myelinisation. Consequently, vitB12 deficiency causes various symptoms, such as megaloblastic anaemia, neurologic signs or pancytopenia. Despite possible severe symptoms, vitB12 deficiency can present asymptomatically. We report six paediatric patients with different aetiologies of vitB12 deficiency ranging from a subtle to a more overt presentation. VitB12 deficiency is a diagnostic challenge due to the lack of consensus on normal values of vitB12 and its co-markers (folate, holotranscobalamin, methylmalonic acid, homocysteine) and the lack in specificity and sensitivity of the serum vitB12 analysis. All cases were treated with parenteral vitB12. Last decades, evidence supporting high dose oral treatment being as effective as the intramuscular (IM) therapy, also in children, is growing. (Acta gastroenterol. belg., 2021, 84, 121-124).
\end{abstract}

Keywords : vitB12 deficiency, cobalamin deficiency, children.

\section{Introduction}

A cobalamin deficiency will commonly be suspected in case of a megaloblastic anaemia. Its clinical significance is not to be underestimated as it can lead to irreversible neurologic damage if left untreated, even in absence of megaloblastic anaemia.

The diagnosis of vitB12 deficiency consists of a combination of at least two criteria : clinical symptoms and vitB12 $<148 \mathrm{pmol} / \mathrm{L}$ or vitB12 $<148 \mathrm{pmol} / \mathrm{L}$ and raised homocysteine (Hcyst) or methylmalonic acid (MMA) in serum or urine.

Based on six clinical cases, this report gives an overview of possible presentations and aetiologies of vitB12 deficiency in a paediatric population.

\section{Case reports}

Laboratory results of each patient are summarised in table 1 .

\section{Patient 1 EXCLUSIVE BREAST FEEDING(VEGAN DIET)}

An eight-month-old female infant presented with solid food refusal and loss of previously reached developmental milestones. She was exclusively breastfed. Her mother adhered to a vegan diet. Clinical examination confirmed neurological regression, but no other signs. Laboratory results showed low vitB12 concentration. Treatment with intramuscular (IM) vitB12 normalised neurological development.

\section{Patient 2 AUTO-IMMUNE GASTRITIS}

A 16-year-old girl with auto-immune polyendocrinopathy, candidiasis and ectodermal dysplasia complained of exercise-induced right hypochondrial pain. An autoimmune hepatitis was diagnosed with associated anti-parietal antibodies (ALL3+/4+), low vitB12 and high Hcyst. Endoscopy revealed auto-immune gastritis. Treatment consisted of steroids and azathioprine for the autoimmune hepatitis and IM vitB12.

\section{Patient 3 CHRONIC ACID BLOCKING DRUGS}

An 18-month-old male patient presented with persistent macrocytic anaemia after an infectious episode. Pallor and fatigue were present for several weeks. Since the age of 4 weeks, he received a maintenance therapy with proton pump inhibitors (PPI) for gastro-oesophagal reflux. He had a normal age-appropriate diet. Treatment consisted of IM vitB12 and PPI cessation.

\section{Patient 4 SHORT BOWEL DISEASE}

A 9-year-old ex-premature with short bowel disease after necrotizing enterocolitis presented with abdominal obstruction for which a small bowel resection with endto-end anastomosis was performed. She displayed a microcytic anaemia and an iron deficiency. Iron therapy normalized the haemoglobin after 6 months. During follow-up, vitB12 status was low and Hcyst increased. Treatment consisted of initial IM administration followed by high dose oral supplements.

\section{Patient 5 CROHN'S DISEASE}

A-15-year-old boy presented with pallor and fatigue, deteriorating over several months. He had a normocytic anaemia with low vitB12, folic acid deficiency, iron deficiency and increased inflammatory parameters. Occult faecal blood was positive and faecal calprotectin was $2779 \mathrm{mg} / \mathrm{kg}$. MR enterography showed a thickened terminal ileum. Ileo-colonoscopy confirmed Crohn's disease which was treated with the Modulife program. The vitB12 deficiency was treated with a single dose IM vitB12 followed by an oral vitB12-B6-folic acid combination.

Correspondence to : Dr. J. Van Vlaenderen, Department of Paediatrics, University Hospital Ghent, Corneel Heymanslaan 10, 9000 Ghent, Belgium. Fax: 0032 (0)93322170.

E-mail : vanvlaenderenjoke@hotmail.com

Submission date : 03/05/2020

Acceptance date : 26/08/2020 
Table 1. - Summary of exact laboratory values (Hb (haemoglobin), MCV (mean corpuscular volume), vitamin B12, Hcyst (homocysteine), MMA (methylmalonic acid)) of each patient with the reference values (RF)

\begin{tabular}{|c|c|c|c|c|c|c|}
\hline & Case 1 & Case 2 & Case 3 & Case 4 & Case 5 & Case 6 \\
\hline $\mathrm{Hb}(\mathrm{g} / \mathrm{dL})$ & $\begin{array}{c}11.9 \\
(\mathrm{RF} 10.5-13.5)\end{array}$ & $\begin{array}{c}12.4 \\
(\mathrm{RF} 12-16)\end{array}$ & $\begin{array}{c}12.5 \\
\text { (RF 12-16) }\end{array}$ & $\begin{array}{c}14.0 \\
(\mathrm{RF} 11.5-15.5)\end{array}$ & $\begin{array}{c}8.9 \\
(\mathrm{RF} 13-16)\end{array}$ & $\begin{array}{c}6.8 \\
\text { (RF 11-14) }\end{array}$ \\
\hline MCV (fL) & $\begin{array}{c}81.8 \\
\text { (RF 70-86) }\end{array}$ & $\begin{array}{c}84.4 \\
(\mathrm{RF} 82.3-96.4) \\
\end{array}$ & $\begin{array}{c}91.6 \\
\text { (RF 82.3-96.4) }\end{array}$ & $\begin{array}{c}84.3 \\
\text { (RF 77-95) }\end{array}$ & $\begin{array}{c}82.1 \\
(\mathrm{RF} 82.3-96.4)\end{array}$ & $\begin{array}{c}111.8 \\
(\mathrm{RF} 73-85)\end{array}$ \\
\hline Cobalamin (pg/mL) & $\begin{array}{c}86 \\
\text { (RF 197-866) } \\
\end{array}$ & $\begin{array}{c}76 \\
\text { (RF 197-866) } \\
\end{array}$ & $\begin{array}{c}172 \\
\text { (RF 197-866) }\end{array}$ & $\begin{array}{c}<150 \\
(\mathrm{RF} 197-866)\end{array}$ & $\begin{array}{c}168 \\
(\mathrm{RF} 197-771) \\
\end{array}$ & $\begin{array}{c}<30 \\
(\text { RF 197-866) }\end{array}$ \\
\hline $\begin{array}{l}\text { Homocysteine } \\
(\mu \mathrm{mol} / \mathrm{L})\end{array}$ & / & $\begin{array}{c}15.1 \\
(\mathrm{RF} 4.7-11.3)\end{array}$ & $\begin{array}{c}12.8 \\
(\mathrm{RF} 4.7-11.3)\end{array}$ & $\begin{array}{c}36.2 \\
(\mathrm{RF} 3.3-8.3)\end{array}$ & $\begin{array}{c}19.5 \\
(\mathrm{RF} 4.7-11.3)\end{array}$ & / \\
\hline $\begin{array}{l}\text { MMA (mmol/ } \\
\text { mol creatin) }\end{array}$ & 1 & l & l & l & l & $\begin{array}{c}421 \\
(\mathrm{RF}<55)\end{array}$ \\
\hline
\end{tabular}

Patient 6 IMERSLUND-GRÄSBECK SYNDROME (IGS)

A 2-year-old boy consulted for "dark"-stained urine associated with fatigue, nausea, cheilitis and stomatitis. His gait was less stable. He had macrocytic anaemia and an extremely low vitB12 associated with significant proteinuria $(1.7 \mathrm{gr} / \mathrm{L})$ and normal kidney biopsy. Parenteral vitB12 administration led to clinical improvement but proteinuria persisted. The combination of proteinuria with vitB12 deficiency raised the suspicion of IGS which was genetically confirmed.

\section{Discussion}

\section{Aetiology deficiency}

Since different mechanisms can lead to vitB12 deficiency it is important to understand its complex metabolic pathway (fig. 1). Based upon the absorption mechanism different aetiologies of vitB12 deficiency can be depicted.

Deficient intake is the most important cause of vitB12 deficiency. All persons consuming fish or meat less than once a week without supplements are at risk
(1). The adult liver contains important vitB12 stores, therefore, deficiency develops only after several years of decreased intake or absorption (2). Newborns, however, have limited vitB12 reserves and will develop symptoms within 2-12 months if no source is provided (Case 1) (3).

Abnormal cobalamin processing in the gastrointestinal tract covers several causes of vitB12 deficiency. Autoimmunity against gastric parietal cells (pernicious anaemia) (case 2) or salivary glands (Sjögren syndrome) leads to deficiency in either intrinsic factor or haptocorrin. Atrophic gastritis or chronic PPI consumption (case 3) results in the inability of cobalamin to bind efficiently to haptocorrin. Finally, in pancreatic insufficiency vitB12 release from haptocorrin and binding to intrinsic factor might be influenced.

Malabsorption can also be the result of different problems. Resection (case 4) or inflammatory destruction of the ileum (case 5), leads to an absent absorption site. Bacterial overgrowth causes consumption or uptakeinhibition of vitB12. Finally, in genetic diseases such as IGS (case 6) mutations in either cubilin or amnionless cause a malfunctioning cubam which leads to vitB12 malabsorption (4).

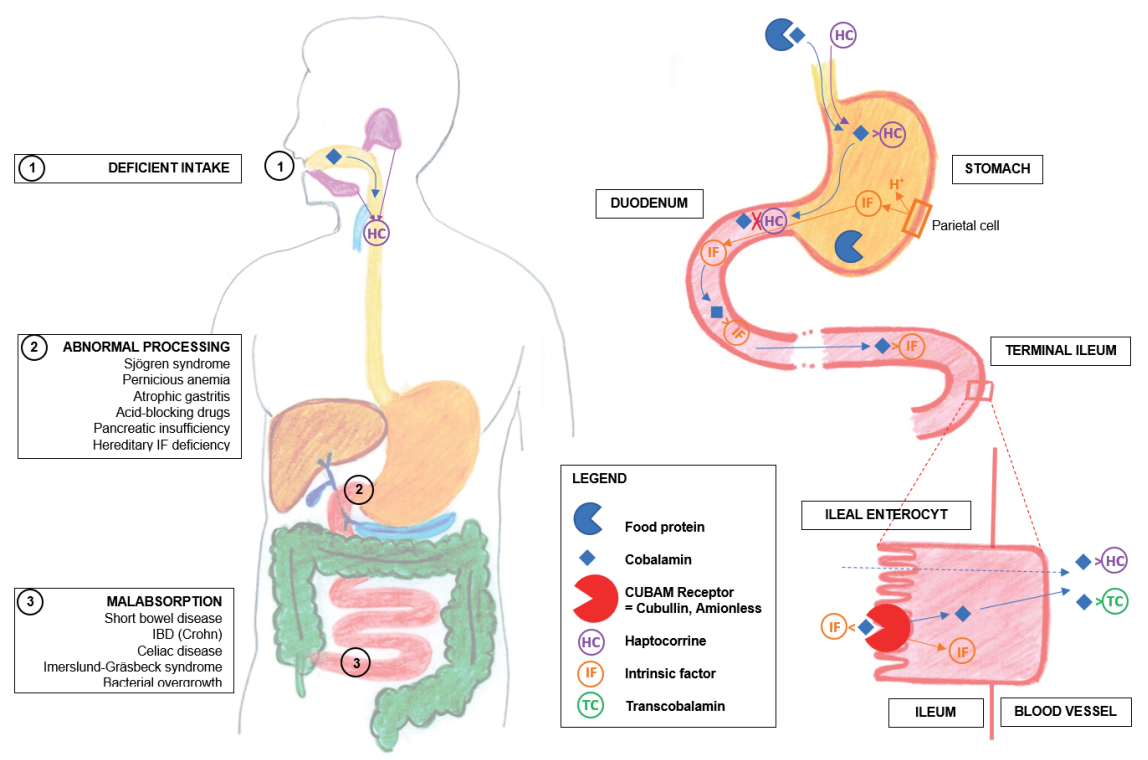

Figure 1. 


\section{Diagnostic challenge}

The best diagnostic parameter of vitB12 deficiency remains debated as there is no consensus on normal serum vitB12 values and false deficiencies are seen in case of folic acid deficiency. Measurement of bioactive holotranscobalamin concentration might be more specific, but this test is not always available (5-7). To overcome this uncertainty, Hcyst and MMA, which will increase in case of vitB12 deficiency, are used as markers of intracellular deficiency. They are increased in more than $98 \%$ of the vitB12 deficient patients $(2,7)$.

When applying all this information in the paediatric context one must bear in mind that almost all the research is done in an adult population.

\section{Therapy}

Treatment of symptomatic vitB12 deficiency is necessary but subclinical vitB12 treatment is debated as transient deficiencies have been described. Asymptomatic patients with known underlying conditions can be monitored periodically instead of routine supplementation (8). Understanding the aetiologies is important as, if possible, the cause of the deficiency needs to be addressed (celiac disease, bacterial overgrowth, Crohn's disease,...) and influences the duration of supplementation (lifelong for IGS, pernicious anaemia, ...) (5).

Until now, the widespread standard treatment in vitB12 deficiency consists of IM injections with varying regimens. There is, however, accumulating evidence that treatment with high dose of oral vitB12 (1-2 mg/d) may be as effective as IM cobalamin, in terms of restoring the vitB12 levels and haematological responses (8). High enteral vitB12 concentrations increase the passive diffusion rate leading to adequate vitB12 levels even in case of a disturbed active absorption (fig. 1). The advantages of oral therapy consist of increased patient convenience, reduced bleeding in anticoagulated patients (7) and reduced health care costs (9).

Most research on oral supplementation is done in adults. There are some studies describing a successful oral treatment in children with vitB12 deficiency (10-15) (table 2). Further research is still needed with better blind randomisation and more participants.

\section{Conclusion}

VitB12 deficiency has a variety of aetiologies and can present as variable clinical pictures, ranging from asymptomatic to overt. Besides a few rare congenital diseases, risk groups are infants, patients with a vegan

Table 2. - Overview of literature about oral treatment of cobalamin in children

\begin{tabular}{|c|c|c|c|c|c|c|}
\hline & $\mathbf{N}$ & Localisation & Inclusion & Treatment & Control & Effect \\
\hline \multirow[t]{2}{*}{$\begin{array}{l}\text { Altay et al. } \\
\text { (1999) (14) }\end{array}$} & 12 & \multirow[t]{2}{*}{$?$} & Selective malabsorption & $1000 \mu \mathrm{g}$ oral & $100 \mu \mathrm{g}$ oral & $\begin{array}{l}\text { Measurement before } \\
\text { and } 3 \mathrm{~h} \text { after oral } \\
\text { administration. } \\
\text { Administration of } 1000 \mu \mathrm{g} \text { : } \\
\text { increase in serum vit B12. }\end{array}$ \\
\hline & 14 & & $\begin{array}{l}\text { Selective malabsorption } \\
\text { initially treated with } \\
\text { parenteral vit B12 }\end{array}$ & $\begin{array}{l}1000 \mu \mathrm{g} \text { oral every } 2 \\
\text { weeks }\end{array}$ & 1 & $\begin{array}{l}\text { Hematological parameters } \\
\text { and serum VB12 levels } \\
\text { remained stable. }\end{array}$ \\
\hline $\begin{array}{l}\text { Verma et al. } \\
(2017)(10)\end{array}$ & 28 & New Delhi, India & $\begin{array}{l}\text { Macrocytic anemia and low } \\
\text { holotranscobalamin levels } \\
\text { Age: } 6 \mathrm{~m}-18 \mathrm{y}\end{array}$ & $\begin{array}{l}500 \mu \mathrm{g} \text { oral } \mathrm{MeCBl} \\
\text { daily } \\
\text { Time: } 1 \text { month }\end{array}$ & 1 & $\begin{array}{l}\text { Significant increase in } \mathrm{Hb} \text {, } \\
\text { reticulocytes, platelets and } \\
\text { vit } \mathrm{B} 12 \text { levels }\end{array}$ \\
\hline \multirow[t]{2}{*}{$\begin{array}{l}\text { Bahadir et al. } \\
(2014)(12)\end{array}$} & \multirow[t]{2}{*}{47} & \multirow[t]{2}{*}{ Trabzon, Turkey } & \multirow[t]{2}{*}{$\begin{array}{l}\text { Nutritional deficiency } \\
\text { Level vit B12: }<200 \mathrm{pg} / \mathrm{mL} \\
\text { Age: } 1 \mathrm{~m}-17 \mathrm{y}\end{array}$} & \multicolumn{2}{|c|}{$\begin{array}{l}\text { 1000 } \mu \mathrm{g} \text { oral CNCbl } \\
\text { 1) daily for a week } \\
\text { 2) alternate day for } 2 \text { weeks } \\
\text { 3) } 2 \text { days a week for } 2 \text { weeks } \\
\text { 4) } \\
\text { once a week }\end{array}$} & \multirow[t]{2}{*}{$\begin{array}{l}\text { Treatment for } 4 \text { months } \\
\text { was effective for } \\
\text { normalizing the vit B12 }\end{array}$} \\
\hline & & & & Time: 4 months & Time: 8 months & \\
\hline $\begin{array}{l}\text { Sezer et al. } \\
(2018)(13)\end{array}$ & 79 & $?$ & $\begin{array}{l}\text { Nutritional deficiency } \\
\text { Level vit B12: }<300 \mathrm{pg} / \mathrm{mL}\end{array}$ & $\begin{array}{l}\text { Oral } \\
\text { - multivitamin } \\
\text { - vit B12 ampules }\end{array}$ & / & $\begin{array}{l}\text { Significant difference } \\
\text { between pre and post } \\
\text { treatment levels of vitamin } \\
\text { B12 }\end{array}$ \\
\hline $\begin{array}{l}\text { Sezer et al. } \\
(2018)(11)\end{array}$ & 142 & Istanbul, Turkey & $\begin{array}{l}\text { Nutritional deficiency } \\
\text { Level vit B12: }<300 \mathrm{pg} / \mathrm{mL} \\
\text { Age: } 1 \mathrm{~m}-18 \mathrm{y}\end{array}$ & $\begin{array}{l}\text { Oral multivitamin } \\
\text { complex daily } \\
\text { - 50mg thiamine } \\
\text { - 250mg pyridoxine } \\
\text { - } 1000 \mu \mathrm{g} \text { CNCbl } \\
\text { Time: } 1 \text { month }\end{array}$ & $\begin{array}{l}\text { Parenteral } \\
\text { 1) } 100 \mu \mathrm{g} \mathrm{CNCbl} \\
\text { daily for } 1 \text { week } \\
\text { 2) } 1000 \mu \mathrm{g} \text { on } \\
\text { alternate days for a } \\
\text { week } \\
\text { 3) } 1000 \mu \mathrm{g} \text { two times } \\
\text { a week for a week } \\
\text { 4) once a week } \\
\text { Time: } 1 \text { month }\end{array}$ & $\begin{array}{l}\text { Both treatment groups } \\
\text { were shown to be effective } \\
\text { in normalizing vitamin B12 } \\
\text { levels }\end{array}$ \\
\hline $\begin{array}{l}\text { Chandelia } \\
\text { et al. (2012) } \\
\text { (15) }\end{array}$ & 150 & New Delhi, India & $\begin{array}{l}\text { Nutritional anaemia } \\
\text { Age: } 6 \mathrm{~m}-5 \mathrm{y}\end{array}$ & $\begin{array}{l}\text { Triple supplement } \\
\text { (iron, folic acid, } \\
\text { cobalamin) PO or IM }\end{array}$ & $\begin{array}{l}\text { Double supplement } \\
\text { (iron, folic acid) }\end{array}$ & $\begin{array}{l}\text { Significantly higher } \\
\mathrm{Hb} \text { irrespective of the } \\
\text { administration route }\end{array}$ \\
\hline
\end{tabular}


diet, auto-immune diseases, chronic PPI treatment and resection or disease of the ileum. The diagnosis can be an arduous challenge as the interpretation of serum vitB12 levels is not reliable. If there is any clinical suspicion or sign of vitB12 deficiency the threshold to measure the more sensitive homocysteine or MMA should be very low.

\section{References}

1. VAN WINCKEL M, VANDE VELDE S, DE BRUYNE R, VAN BIERVLIET S. Clinical practice : vegetarian infant and child nutrition. European journal of pediatrics, 2011, 170(12) : 1489-94

2. STABLER SP. Clinical practice. VitB12 deficiency. The New England journal of medicine, 2013, 368(2) : 149-60.

3. IDE E, VAN BIERVLIET S, THIJS J, VANDE VELDE S, DE BRUYNE $\mathrm{R}$, VAN WINCKEL M. Solid food refusal as the presenting sign of vitB12 deficiency in a breastfed infant. European journal of pediatrics, 2011, 170(11) : 1453-5.

4. GRASBECK R. Imerslund-Grasbeck syndrome (selective vitamin $\mathrm{B}(12)$ malabsorption with proteinuria). Orphanet journal of rare diseases, 2006, 1 : 17.

5. SHIPTON MJ, THACHIL J. VitB12 deficiency - A 21st century perspective. Clinical medicine (London, England), 2015, 15(2) : 145-50.

6. APARICIO-UGARRIZA R, PALACIOS G, ALDER M, GONZALEZGROSS M. A review of the cut-off points for the diagnosis of vitB12 deficiency in the general population. Clinical chemistry and laboratory medicine, 2015, 53(8) : 1149-59.
7. DEVAlia V, HAMilton MS, MOLlOY AM, British Committee for Standards in $\mathrm{H}$. Guidelines for the diagnosis and treatment of cobalamin and folate disorders. British journal of haematology, 2014, 166(4) : 496-513.

8. WANG H, LI L, QIN LL, SONG Y, VIDAL-ALABALL J, LIU TH. Oral vitB12 versus intramuscular vitB12 for vitB12 deficiency. The Cochrane database of systematic reviews, 2018, 3 : CD004655.

9. VIDAL-ALABALL J, BUTLER CC, POTTER CC. Comparing costs of intramuscular and oral vitB12 administration in primary care : a costminimization analysis. The European journal of general practice, 2006, 12(4) : 169-73.

10. VERMA D, CHANDRA J, KUMAR P, SHUKLA S, SENGUPTA S. Efficacy of oral methylcobalamin in treatment of vitB12 deficiency anemia in children. Pediatric blood \& cancer, 2017, 64(12)

11. SEZER RG, AKOGLU HA, BOZAYKUT A, OZDEMIR GN. Comparison of the efficacy of parenteral and oral treatment for nutritional vitB12 deficiency in children. Hematology (Amsterdam, Netherlands), 2018, 23(9) : 653-7.

12. BAHADIR A, REIS PG, ERDURAN E. Oral vitB12 treatment is effective for children with nutritional vitB12 deficiency. Journal of paediatrics and child health, 2014, 50(9) : 721-5

13. SEZER RG, BOZAYKUT A, AKOGLU HA, OZDEMIR GN. The Efficacy of Oral VitB12 Replacement for Nutritional VitB12 Deficiency. Journal of pediatric hematology/oncology, 2018, 40(2) : e69-e72.

14. ALTAY C, CETIN M. VitB12 absorption test and oral treatment in 14 children with selective vitB12 malabsorption. Pediatric hematology and oncology, 1999, 16(2) : 159-63.

15. CHANDELIA S, CHANDRA J, NARAYAN S, ANEJA S, CHAWLA HM, SHARMA S, et al. Addition of cobalamin to iron and folic acid improves hemoglobin rise in nutritional anemia. Indian journal of pediatrics, 2012, 79(12) : 1592-6. 